\title{
A case of lichenoid photosensitive eczema in a HIV seropositive patient
}

\author{
R Gayathri', AK Bubna, M Krishnakanth, S Adikrishnan, S Murugan, V Mahalakshmi, S Anandan, R Sudha \\ From 2nd International Science Symposium on HIV and Infectious Diseases (HIV SCIENCE 2014) \\ Chennai, India. 30 January - 1 February 2014
}

\section{Background}

Cutaneous changes in HIV have protean manifestations. We hereby present a case of a lichenoid photosensitive eczema in a HIV positive patient.

\section{Case report}

A 32 year old female presented with burning and itching sensation with hyperpigmentation over the sun exposed areas- face, neck, back and arms. No history of any blisters over skin or hypertrichosis. History of weight loss of more than $6 \mathrm{kgs}$ was documented in a month. Patient's husband was a driver with history of multiple unprotected sexual exposures with CSW. No history of any oral or genital ulcers, artharlgia, diarrhoeal episodes, evening rise of temperature and cough with expectoration.

$\mathrm{O} / \mathrm{E}$ : Erythematous and edematous plaques present over sun exposed areas. Hyperpigmention with lichenoid hue + over malar region, neck folds , back and arms Multiple excoriation marks, hyperpigmented papules and plaques present over bilateral arms, legs, and ante cubital fossa.Oral cavity, genital mucosas were normal. No generalised lymphadenopathy. Routine laboratory investigations were normal. Mantoux test, RPR, Chest $\mathrm{X}$ - ray, USG abdomen pelvis was normal. Skin biopsy was suggestive of interface dermatitis. HIV (1 and 2) ELISA was reactive which was confirmed by Western blot. The CD4 count was 610/cumm.

\section{Discussion}

Lichenoid photosensitive eczema is known to manifest in the terminal stage of the HIV infection in individuals with a low CD4 count. Our patient is a newly diagnosed

\footnotetext{
* Correspondence: sharwan@gmail.com

Department of Dermatology, Venereology and Leprosy, Sri Ramachandra Medical College, Chennai, India
}

(C) 2014 Gayathri et al; licensee BioMed Central Ltd. This is an Open Access article distributed under the terms of the Creative Commons Attribution License (http://creativecommons.org/licenses/by/4.0), which permits unrestricted use, distribution, and reproduction in any medium, provided the original work is properly cited. The Creative Commons Public Domain Dedication waiver (http:// creativecommons.org/publicdomain/zero/1.0/) applies to the data made available in this article, unless otherwise stated.
Submit your next manuscript to BioMed Central and take full advantage of:

- Convenient online submission

- Thorough peer review

- No space constraints or color figure charges

- Immediate publication on acceptance

- Inclusion in PubMed, CAS, Scopus and Google Scholar

- Research which is freely available for redistribution Submit your manuscript at
www.biomedcentral.com/submit C BioMed Central

\section{Biomed Central}

case of HIV with a relatively high CD4 count manifesting with photosensitive eczema. This case is presented for its rarity.

Published: 27 May 2014

Cite this article as: Gayathri et al:: A case of lichenoid photosensitive eczema in a HIV seropositive patient. BMC Infectious Diseases 2014 14(Suppl 3):P54. 